Check for updates

Cite this: RSC Adv., 2018, 8, 22482

Received 10th April 2018

Accepted 13th June 2018

DOI: $10.1039 / c 8 r a 03057 j$

rsc.li/rsc-advances

\title{
Imido-substituted triazines as dehydrative condensing reagents for the chemoselective formation of amides in the presence of free hydroxy groups $\uparrow$
}

\author{
Masanori Kitamura, (D) Suguru Sasaki, Riho Nishikawa, Kohei Yamada (D) \\ and Munetaka Kunishima (D) *
}

In this paper, we discuss the synthesis of imido-substituted chlorotriazines and demonstrate their use in dehydrative condensation reactions. Chemoselective amide-forming reactions of amino alcohols using succinimido-substituted chlorotriazine (2A) proceeded smoothly. Occasionally, nonselectivity was problematic during the synthesis of hydroxy-substituted amides. Moreover, it was noteworthy that this method was applicable to hydroxy-substituted carboxylic acids that could have formed a lactone or an ester during the carboxylic acid activation step. The imido-substituted chlorotriazine (2A) was superior to the amido-substituted chlorotriazine and 2-chloro-4,6-dimethoxy-1,3,5-triazine (CDMT) in terms of reaction rates and yields.

\section{Introduction}

Amides are important functional groups that can be found in many materials, pharmaceuticals, and natural products. Therefore, they are routinely synthesized from carboxylic acids and amines in both the laboratory and industry. ${ }^{1}$ Chemoselective amide-forming reactions of amino alcohols have long been investigated ${ }^{2-4}$ because many important compounds contain this combination of functional groups, including antiinflammatory drugs such as acetaminophen, ${ }^{2}$ cosmetics, ${ }^{5}$ and surfactants. ${ }^{6}$ However, nonselective $\mathrm{N}$ - and $\mathrm{O}$-acylation of amino alcohols is often problematic during amide synthesis., ${ }^{2,3}$ In addition, the activation of a hydroxy-substituted carboxylic acid is difficult using conventional methods because lactone or ester formation is possible during carboxylic acid activation.

We have developed a class of trizaine-based dehydrative condensing reagents [(4,6-dimethoxy-1,3,5-triazin-2-yl)trialkylammonium salts, DMT-Ams], including 4-(4,6-dimethoxy1,3,5-triazin-2-yl)-4-methylmorpholinium chloride (DMT-MM), which can be employed in aqueous or alcoholic solvents (Scheme 1. See the ESI $\dagger$ for the detailed reaction mechanism). ${ }^{\mathbf{8}, 9}$ These reagents were prepared from 2-chloro-4,6-dimethoxy1,3,5-triazine (CDMT) and $N$-methylmorpholine (NMM) or tertiary amines (tert-amines). ${ }^{9}$ For the preparation of functional

Faculty of Pharmaceutical Sciences, Institute of Medical, Pharmaceutical, and Health Sciences, Kanazawa University, Kakuma-machi, Kanazawa 920-1192, Japan. E-mail: kunisima@p.kanazawa-u.ac.jp

$\dagger$ Electronic supplementary information (ESI) available. CCDC 1834905. For ESI and crystallographic data in CIF or other electronic format see DOI: 10.1039/c8ra03057j
DMT-Ams that selectively activate carboxylic acids, various tertamines were studied. ${ }^{10,11}$ However, in most cases, the substituents on the triazine ring were limited to dimethoxy groups. Considering that substituents on the triazine would be important for the development of a diverse family of dehydrative condensing reagents, we studied chlorotriazines and their ammonium salts. As part of this project, we have recently reported that electron-withdrawing amido-substituted triazines (1 and 3) showed a higher reactivity for dehydrative condensing reactions. ${ }^{12}$ According to the Hammett substituent constants, ${ }^{13}$ imido-substituents $\left(\sigma_{\mathrm{m}}=0.34\right.$ for the succinimido group) are more electron-withdrawing than methoxy- $\left(\sigma_{\mathrm{m}}=0.12\right)$ and

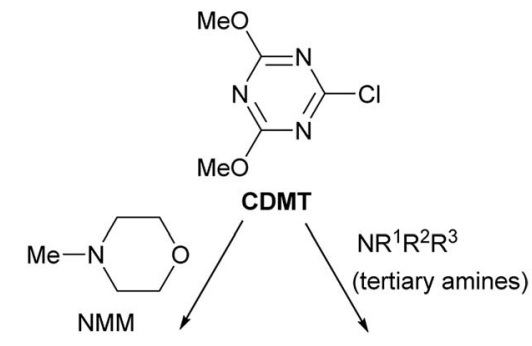<smiles></smiles>

1: $X=$ amido 2: $X=$ imido $N R^{1} R^{2} R^{3}$<smiles>COc1nc(OC)nc([N+]2(C)CCOCC2)n1</smiles><smiles>[R][Y]([R])([H])c1nc(OC)nc(OC)n1</smiles>

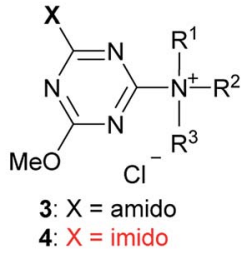

Scheme 1 Triazine-based condensing reagents. 
amido-substituents $\left(\sigma_{\mathrm{m}}=0.21\right.$ for the acetamido group); therefore, a higher reactivity for condensation was expected. In this study, triazines with even more electron-withdrawing imido-substituents ( 2 and 4 ) were investigated, including the chemoselective acylation of amino alcohols and activation of hydroxy-substituted carboxylic acids.

\section{Results and discussion}

Rapidly available imides, such as succinimide, phthalimide, maleimide, and glutarimide, as substituents for triazine, were studied because condensing reagents should be inexpensive, especially if they are to be used in large-scale syntheses (2A-2D in Fig. 1). Moreover, instead of cyclic imides, linear diacetamide was also considered (2E in Fig. 1). For simplification, only one methoxy group on CDMT was replaced with an imidosubstituent (Fig. 1).

It was difficult to determine the general reaction conditions for the synthesis of the above-mentioned imido-substituted chlorotriazines because the different imides possessed unequal reactivities (Scheme 2). The succinimido-substituted compound $\mathbf{2 A}$ was obtained from the reaction of 2,4-dichloro6-methoxy-1,3,5-triazine (DCMT) with the succinimide anion in tetrahydrofuran (THF) at $55{ }^{\circ} \mathrm{C}$ (55\% isolated yield). $2 \mathrm{~B}$ was prepared in a $58 \%$ isolated yield using the commercially available phthalimide potassium salt and DCMT in the presence of 18-crown-6 at ambient temperature. However, 2C could not be obtained under similar reaction conditions using DCMT in the presence of various bases. Compared to the five-membered ring succinimide, the nucleophilicity of the six-membered glutarimide anion toward DCMT was unexpectedly low. Despite the decreased delocalization of the negative charge for the glutarimide anion as expected from their $\mathrm{p} K_{\mathrm{a}}$ values (11.4 for glutarimide and 9.6 for succinimide), the yield of 2D was low. ${ }^{\mathbf{1 4}}$ Shielding of the nitrogen lone pairs of the imide anion by the two adjacent carbonyl oxygen groups, as expected from X-ray crystal structure analysis of glutarimide ${ }^{\mathbf{1 5}}$ and succinimide, ${ }^{\mathbf{1 6}}$ may explain the reduced reactivity. Glutarimide had a smaller $\mathrm{O}=\mathrm{C}-\mathrm{N}$ bond angle $\left(119.60^{\circ}\right.$ for glutarimide and $123.86^{\circ}$ for succinimide) and larger $\mathrm{C}-\mathrm{N}-\mathrm{C}$ bond angle $\left(126.90^{\circ}\right.$ for glutarimide and $112.62^{\circ}$ for succinimide). 2D was successfully crystalized and the structure was confirmed by X-ray single crystal

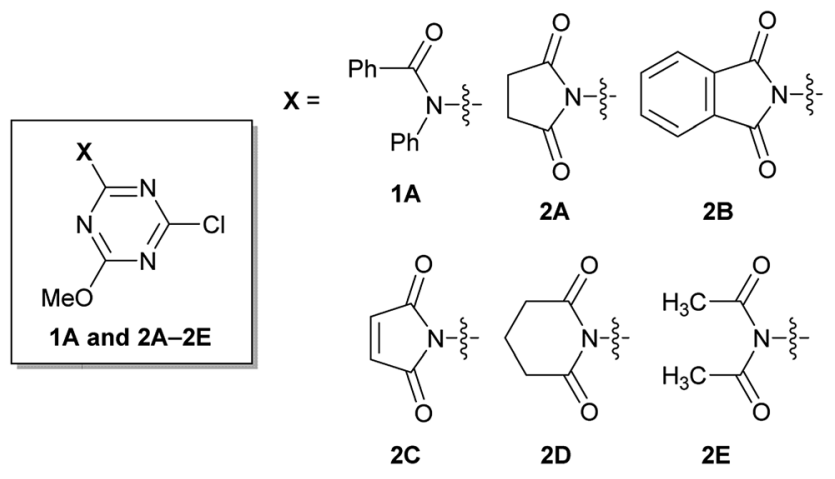

Fig. 1 Structures of amido- or imido-substituted chlorotriazines.

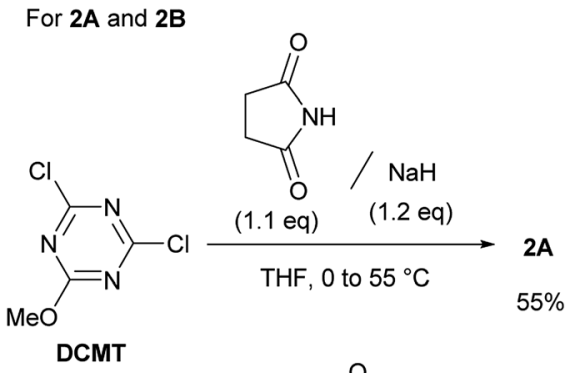<smiles>CN1C(=O)c2ccccc2C1=O</smiles>

(1.1 eq)

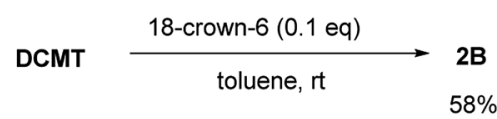

For 2D
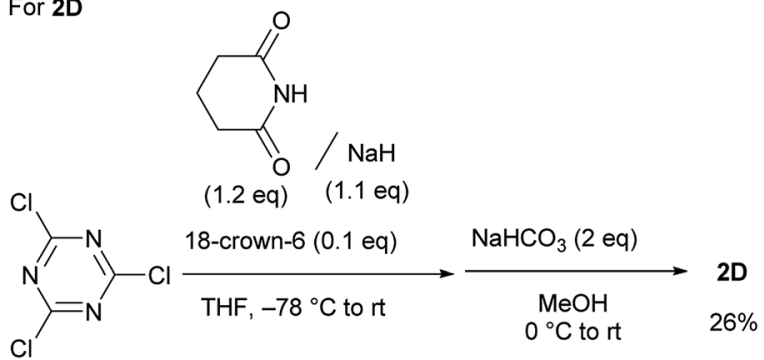

Scheme 2 Synthesis of chlorotriazines (2A, 2B, and 2D).

structure analysis (see the ESI $\dagger$ ). In the case of the linear diacetamide, 2E was difficult to prepare. Despite the consumption of DCMT, only side products were detected.

Next, we examined the preparation of the imido-substituted condensing reagents (4). Although the desired $\mathbf{4}$ would be formed using NMM and $N$-methylpiperidine (NMP) as the tertamines, the purities of $\mathbf{4}$ were low because demethylation (by the chloride anion) and hydrolysis occurred during the isolation steps. To prevent demethylation, the synthesis of 4 was attempted in the presence of nonnucleophilic perchlorate anions; however, hydrolysis was still problematic. It was assumed that the strong electron-withdrawing effect of the imido group made isolation difficult.

For convenient evaluation of the reactivity of these prepared chlorotriazines (2A, 2B, and 2D), the corresponding DMT-Ams (10) were generated in situ and used for coupling of carboxylic acid 5a and amine $\mathbf{6 a}$ (Scheme 3 and Table 1). ${ }^{9}$ Chlorotriazine $\mathbf{2 A}$ was added to a mixture of $\mathbf{5 a}, \mathbf{6 a}$, and NMM at ambient temperature in $\mathrm{MeOH}$ (Table 1 , entry 1). ${ }^{\mathbf{1 7}}$ Amide 7a was only obtained in a $69 \%$ yield. The formation of side product $8 \mathbf{A}(3 \%)$ and methyl ester 9a (11\%) was also observed. The yield of 9a using $2 \mathrm{~A}$ was larger than that using CDMT (2\% for CDMT), indicating that the electrophilicity of triazinyl ester $\mathbf{1 1}$ toward methanol was increased because of the succinimido group on the triazine ring. In THF, the increased yield of the side product $\mathbf{8 A}$ (35\% for $2 \mathrm{~A}$ ) was observed, in contrast to CDMT (18\% for CDMT), implying a similar electron-withdrawing effect of the 

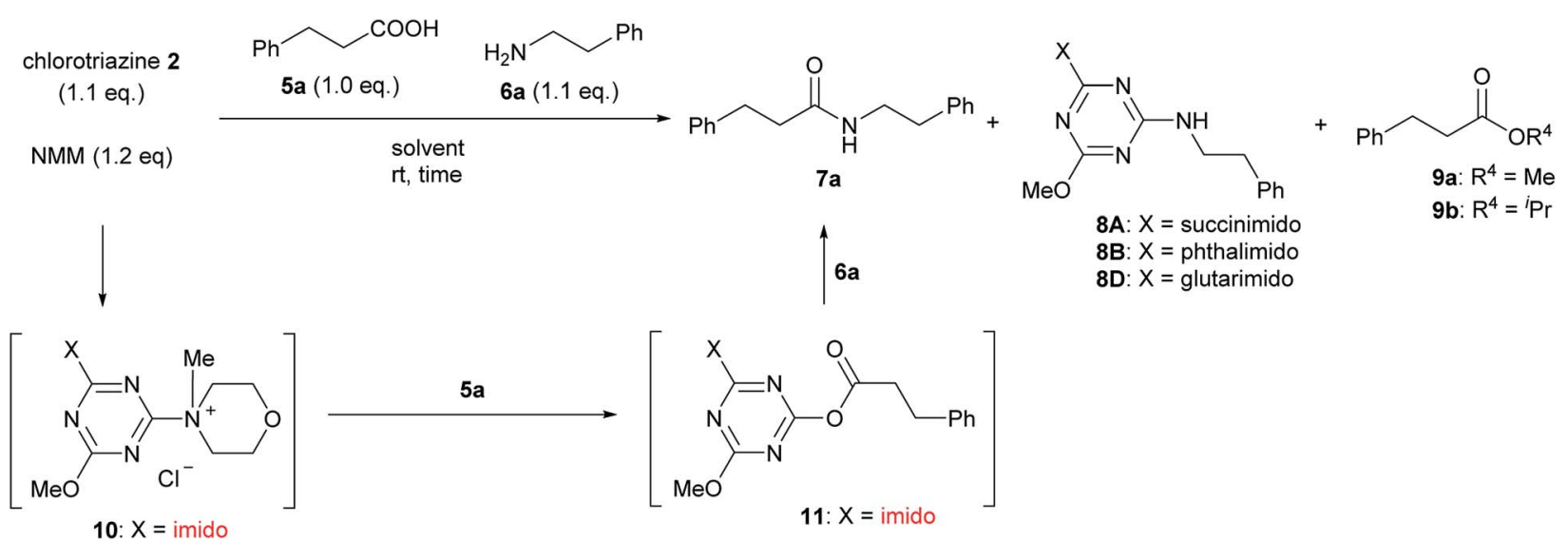

Scheme 3 Amide-forming reactions of carboxylic acid 5a and amine 6a using imido-substituted chlorotriazines 2.

Table 1 Amide-forming reactions using the imido-substituted chlorotriazines/NMM system

\begin{tabular}{|c|c|c|c|c|c|c|c|c|c|c|c|c|}
\hline \multirow{2}{*}{ Entry } & \multirow{2}{*}{ Chlorotriazine } & \multicolumn{11}{|c|}{ Yield $^{a}(\%)$} \\
\hline & & \multicolumn{4}{|c|}{ In $\mathrm{MeOH}$} & \multicolumn{3}{|c|}{ In THF } & \multicolumn{4}{|c|}{ In ${ }^{\mathrm{i}} \mathrm{PrOH}$} \\
\hline 1 & $2 \mathrm{~A}$ & 69 & 3 & 11 & $3 \mathrm{~h}$ & 62 & 35 & $3 \mathrm{~h}$ & 84 & 2 & Trace & $30 \mathrm{~min}$ \\
\hline 2 & $2 B$ & 67 & $-^{b}$ & 15 & $3 \mathrm{~h}$ & 53 & $-b$ & $3 \mathrm{~h}$ & $-c$ & $-c$ & $-^{c}$ & $-^{c}$ \\
\hline
\end{tabular}

${ }^{a}$ Based on ${ }^{1} \mathrm{H}$ NMR. ${ }^{b}$ Not determined. ${ }^{c}$ Not conducted.

succinimido group. ${ }^{18}$ To prevent the alcoholysis of 11, the reaction was conducted in ${ }^{\mathrm{i}} \mathrm{PrOH}$ and the yield of $7 \mathbf{a}$ was improved to $84 \%$ (Table 1, entry 1). Due to the fact that similar results were obtained for $\mathbf{2 B}$ and $\mathbf{2 D}$ (Table 1, entries 2 and 3), the influence from the kind of imido-structures was thought to be small for the condensing reactions. Moreover, the phthalimido-substituted chlorotriazine (2B) was not very soluble in THF and alcohol; therefore, only succinimidosubstituted chlorotriazine $\mathbf{2 A}$ and glutarimido-substituted chlorotriazine 2D were selected for further studies.

The formation of the side product $\mathbf{8}$ was assumed to result from chlorotriazine 2 being more electrophilic than 10 or $\mathbf{1 1}$. Thus, the addition of amine $\mathbf{6}$ after the formation of $\mathbf{1 1}$ should prevent the formation of $\mathbf{8}$ (Table 2). Accordingly, amine $\mathbf{6}$ was added to the preformed mixture of chlorotriazine, NMM, and carboxylic acid $\mathbf{5}$ in THF. In this solvent, ester 9 would never be formed. In the amide-forming reactions of 2-phenylpropionic acid (5a) with 2-phenethylamine (6a), aniline $(\mathbf{6 b})$, or 4(ethoxycarbonyl)aniline (6c) (the nucleophilicity of these amines decreases in this order), imido-substituted 2A and 2D afforded better yields than CDMT (Table 2, entries 1-9). From the viewpoints of atom economy, starting material costs, and synthetic yields, $\mathbf{2 A}$ was selected for further studies. In the case of sterically hindered isobutyric acid (5b, entries 10 and 11$), 2 \mathbf{A}$ also afforded amide $\mathbf{7 d}$ in a better yield than that using CDMT. When the more sterically hindered pivalic acid (5c) was used (entries 12-17), different reactivities between 2A and CDMT were observed for aniline $\mathbf{6 b}$ (entry 16 versus 17 ). Although it was thought that the benzoic acid derivative (5d, with electronwithdrawing nitro groups) might form intermediate 11 slowly, 2A afforded product $7 \mathbf{h}$ in an excellent yield compared to CDMT (Table 2, entry 18 versus 19). This method is also effective for formation of a peptide bond, i.e., condensation of Boc-Leu-OH (5e) and H-Phe-OMe (6e) afforded the corresponding dipeptide (7i) in $94 \%$ NMR yield as a single diastereomer (Table 2, entry 20). As indicated in entry 18 of Table 2, purification by only extraction and recrystallization without column chromatography was also possible.

From these results, it is unambiguous that the succinimidosubstituted chlorotriazine $\mathbf{2 A}$ was more reactive than CDMT, and less sterically hindered alcoholic solvents (especially methanol) are unsuitable for carrying out the condensing reactions because of alcoholysis of $\mathbf{1 1}$. However, we anticipated that the competing alcoholysis against aminolysis would be reduced when lower concentrations of alcohols were used. Namely, chemoselective amide forming reactions could be effective even using carboxylic acids $\mathbf{5}$ and amines $\mathbf{6}$ having free hydroxy groups. Thus, we tested 6-hydroxyhexanoic acid (5f) as it would be susceptible to an intramolecular lactone-formation or an intermolecular ester-formation during the carboxylic acid activation step (Table 3, entries 1 and 2). The desired amide $7 \mathbf{j}$ was obtained in a good yield compared to CDMT under the reaction conditions used in Table 2 . When amino alcohols such as benzyl(2-hydroxyethyl)amine (6f, Table 3, entries 3 and 4) and $\mathrm{N}$-(2-hydroxyethyl)aniline (6g. Table 3 , entries 5 and 6$)$ were employed, better yields of amide products ( $7 \mathbf{k}$ and $7 \mathbf{l}$ ) were 
Table 2 The scope of amide-forming reactions of carboxylic acids 5 with amines 6

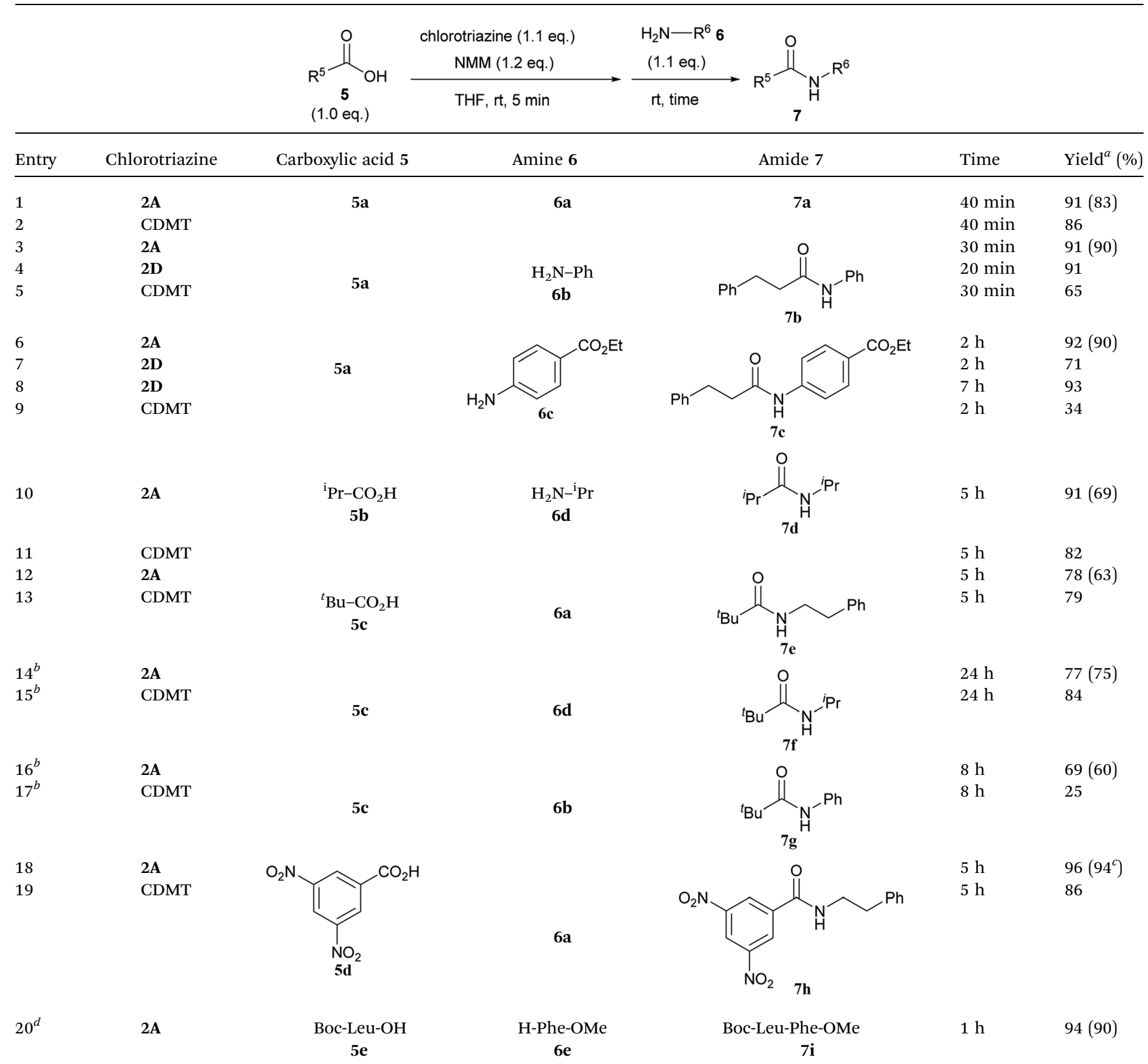

${ }^{a}$ NMR yields. Isolated yields are given in the parentheses. ${ }^{b}$ Reaction time of the first step was 15 min. ${ }^{c}$ The desired product was isolated in $81 \%$ yield only by extraction and recrystallization without column chromatography. ${ }^{d}$ Boc-Leu-OH (1.0 eq.), 2 A (1.05 eq.), NMM (1.2 eq.), H-Phe-OMe-HCl (1.2 eq.), and $\mathrm{EtN}^{\mathrm{i}} \operatorname{Pr}_{2}$ (1.2 eq.) were used.

observed, even in the presence of the competing free hydroxy groups. Although the chemoselective acylation of 4-aminophenol (6h) using EDC and HOBt in the presence of a surfactant was insufficient, ${ }^{2} \mathbf{2 A}$ afforded the desired product $\mathbf{7 m}$ chemoselectively. Even though Boc-Tyr-OH having the phenolic hydroxy group was used as the starting material, the desired dipeptide ( $7 \mathbf{n}$ ) was obtained in $80 \%$ NMR yield and $71 \%$ isolated yield (Table 3, entry 9).

To clarify the reactivity of $2 \mathrm{~A}$ compared with the amidosubstituted chlorotriazine 1A and CDMT, the formation of 71 under similar conditions used in Tables 2 and 3 was investigated kinetically with ${ }^{1} \mathrm{H}$ NMR spectroscopy (Fig. 2). The reaction rate with $\mathbf{2 A}$ was faster than that with $\mathbf{1 A}$ or CDMT.

From the study of the DMT-Ams, we previously elucidated that the reactivity of tert-amines toward CDMT was strongly influenced by their steric hinderance; ${ }^{9}$ that is, a $\beta$-alkyl group toward the nitrogen lone pair in a gauche relationship remarkably hampers the nucleophilic attack on CDMT. Because of this effect, $N$-ethylmorpholine, $N$-ethylpiperidine, and triethylamine are unable to react with CDMT to afford DMT-Ams at ambient temperature. Contrastingly, the imido- 
Table 3 Amide-forming reactions in the presence of free hydroxy groups

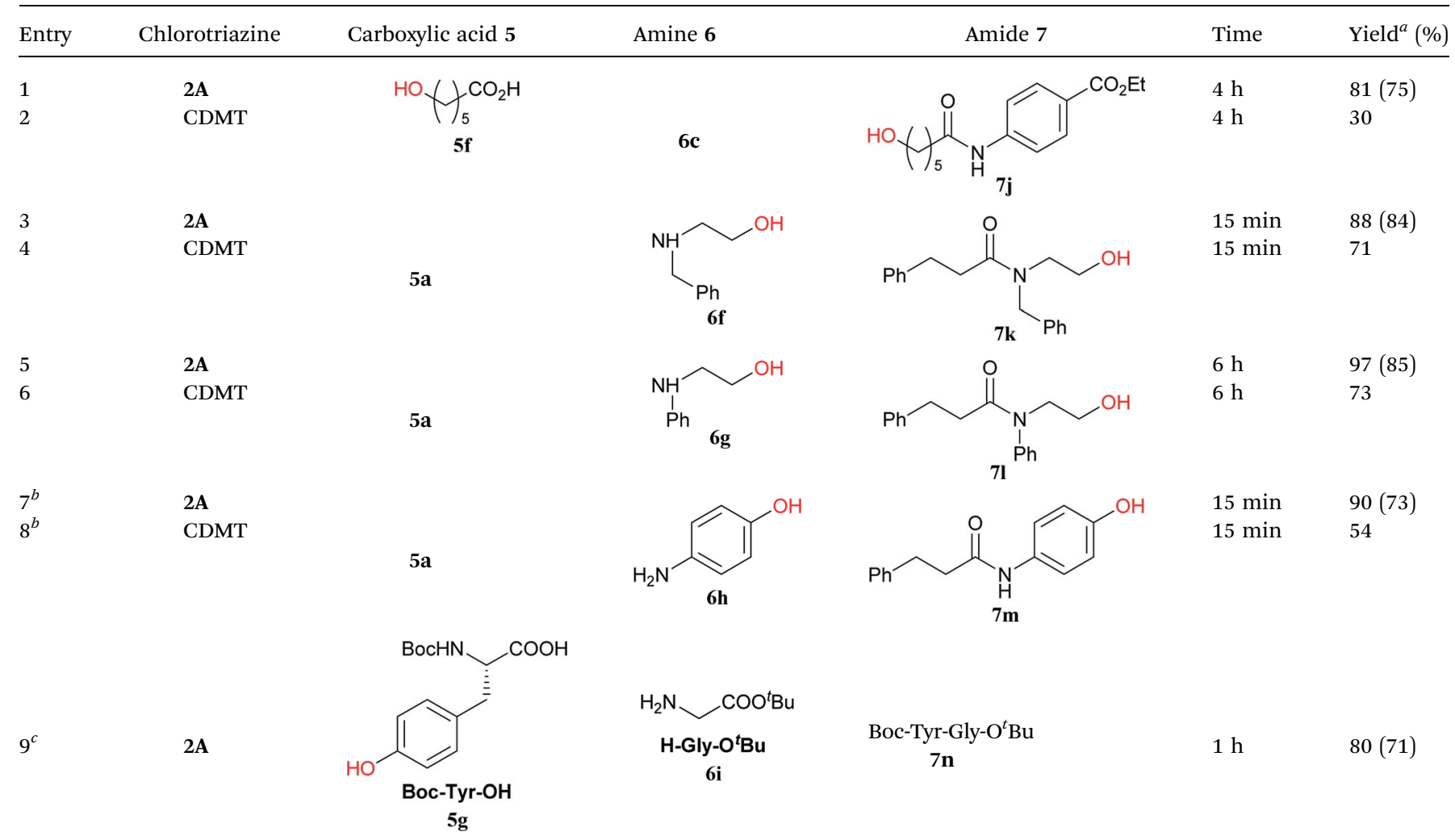

${ }^{a}$ NMR yields. Isolated yields are given in the parentheses. ${ }^{b}$ 3-Phenylpropionic acid (1.1 eq.), $2 \mathrm{~A}$ or CDMT (1.0 eq.), NMM (1.05 eq.), and 4aminophenol (1.0 eq.) were used. ${ }^{c}$ Boc-Tyr-OH (1.0 eq.), $2 \mathrm{~A}$ (1.0 eq.), NMM (1.2 eq.), H-Gly-O ${ }^{t} \mathrm{Bu} \cdot \mathrm{HCl}\left(2.0\right.$ eq.), and EtN ${ }^{\mathrm{i}} \mathrm{Pr}_{2}$ (2.0 eq.) were used.

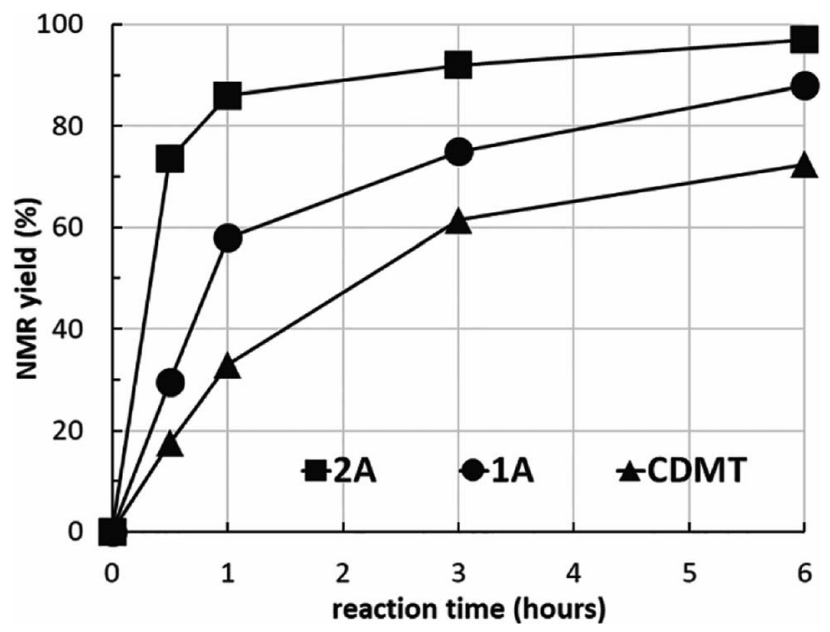

Fig. 2 Kinetic study of amide $7 \mathrm{l}$ formation using 2A, 1A, and CDMT.

substituted chlorotriazine $\mathbf{2 A}$ reacted with these tert-amines, resulting in the formation of $7 \mathbf{a}$ (Table 4). The strong electron-withdrawing ability of the succinimido group was thought to be responsible for overcoming this difficulty, thus enabling the use of various tert-amines for condensing reagents. ${ }^{10,11}$
Table 4 Amide-forming reactions using sterically hindered tertamines that were incapable of reacting with CDMT

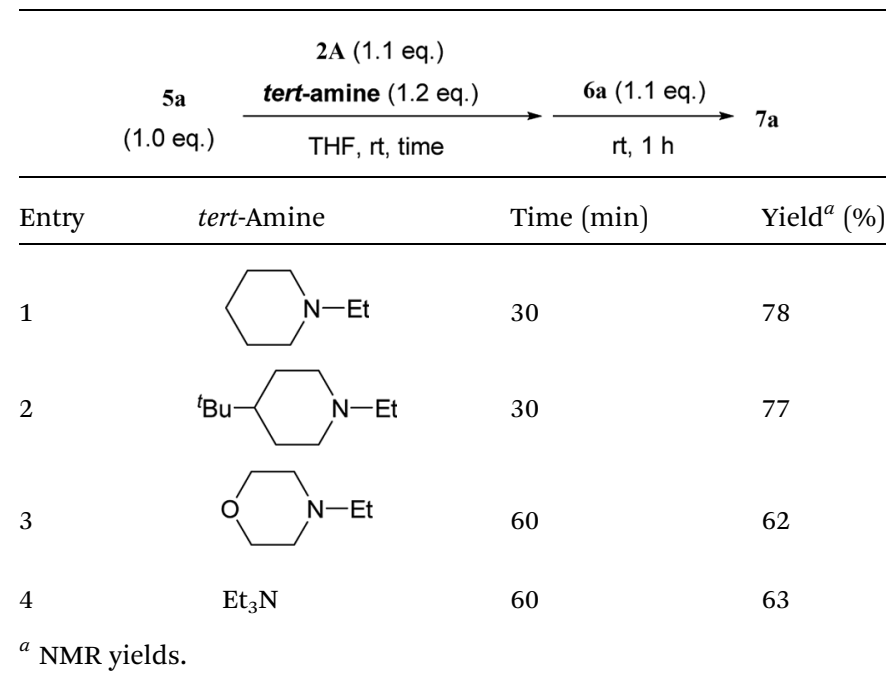

\section{Conclusion}

We have developed imido-substituted chlorotriazines (2) and demonstrated their use in efficient dehydrative condensing reactions between carboxylic acids and amines. Chemoselective amide-forming reactions using amino alcohols with 
succinimido-substituted $\mathbf{2 A}$ were successfully achieved. In addition, we demonstrated that $\mathbf{2 A}$ was an effective reagent for the chemoselective condensing reaction of hydroxy-substituted carboxylic acids that could form a lactone or an ester during the activation step. In terms of reaction rates and amide yields, $2 \mathbf{A}$ was superior to the amido-substituted chlorotriazine $\mathbf{1 A}$ and CDMT. Sterically hindered tert-amines that would never react with CDMT at ambient temperature, such as $\mathrm{N}$-ethylmorpholine, $N$-ethylpiperidine, and triethylamine, were successfully employed in the formation of DMT-Ams with 2A. These results will contribute to the development of novel functionalized triazine-based condensing reagents and tert-amine-catalyzed amide-forming reactions.

\section{Experimental}

\section{General methods}

Nuclear magnetic resonance $\left[{ }^{1} \mathrm{H}\right.$ NMR $(400$ or $600 \mathrm{MHz})$ and ${ }^{13} \mathrm{C}$ NMR (100 or $150 \mathrm{MHz}$ )] spectroscopy was carried out on JEOL JNM-ECS400 and JEOL JNM-ECA600 spectrometers. Chemical shifts for ${ }^{1} \mathrm{H}$ NMR were reported as $\delta$ values relative to tetramethylsilane (TMS). The coupling constants for ${ }^{1} \mathrm{H}$ NMR were reported in hertz $(\mathrm{Hz})$. The following abbreviations were used for reporting the spin multiplicity: $\mathrm{s}=$ singlet, $\mathrm{d}=$ doublet, $\mathrm{t}=$ triplet, $\mathrm{q}=$ quartet, quin = quintet, $\mathrm{m}=$ multiplet, and $\mathrm{br}=$ broad. Chemical shifts for ${ }^{13} \mathrm{C}$ NMR were reported as $\delta$ values relative to the center line of the deuterochloroform triplet at $77.16 \mathrm{ppm}$. Mass spectra were measured on a JEOL JMS-T100TD spectrometer (DART- and ESI-MS). Analytical thin-layer chromatography (TLC) was performed on Merck precoated analytical plates, $0.25 \mathrm{~mm}$ thick, silica gel $60 \mathrm{~F}_{254}$. Flash chromatography separation was performed using Kanto Chemical silica gel $60 \mathrm{~N}$ (spherical, neutral, 40-100 mesh) unless otherwise noted. All Reagents were of commercial grade and were used without further purification unless otherwise noted. Anhydrous THF and toluene were purchased from commercial sources. All reactions that are sensitive to oxygen or moisture were conducted under a $\mathrm{N}_{2}$ atmosphere. The ${ }^{1} \mathrm{H}$ NMR spectral data for 2-methoxy4-phenethylamino-6-succinimido-1,3,5-triazine (8A) and 2glutarimido-4-methoxy-6-phenethylamino-1,3,5-triazine (8D) were consistent with those of authentic samples prepared from $2 \mathbf{A}$ and 2D (see the ESI $\dagger$ for synthetic details). ${ }^{1} \mathrm{H}$ NMR spectral data for methyl 3-phenylpropanoate $(\mathbf{9 a})^{\mathbf{1 9 , 2 0}}$ and 2-propyl 3-phenylpropanoate $(\mathbf{9 b})^{\mathbf{2 0 , 2 1}}$ were consistent with the referenced chemical shift values. ${ }^{1} \mathrm{H}$ NMR spectral data of the isolated amide products $7 \mathbf{a},{ }^{22} \mathbf{7 b},{ }^{23,24} \mathbf{7 d},{ }^{25} 7 \mathbf{e},{ }^{26} \mathbf{7 f},{ }^{27} \mathbf{7 g},{ }^{28} \mathbf{7 i},{ }^{29} \mathbf{7 m},{ }^{30}$ and $\mathbf{7 n}$ (ref. 31) were identical to known literature values (see the ESI $\dagger$ ).

\section{Experimental procedure and characterization data}

2-Chloro-4-methoxy-6-succinimido-1,3,5-triazine (2A). To a THF solution $(70 \mathrm{~mL})$ of sodium hydride $(60 \%, 1.44 \mathrm{~g}, 36.0$ mmol), succinimide $(3.27 \mathrm{~g}, 33.0 \mathrm{mmol})$ was added at $0{ }^{\circ} \mathrm{C}$. To this reaction mixture, a THF solution $(30 \mathrm{~mL})$ of 2,4-dichloro-6methoxy-1,3,5-triazine $(5.40 \mathrm{~g}, 30.0 \mathrm{mmol})$ was added dropwise at ambient temperature. After stirring for $30 \mathrm{~h}$ at $55{ }^{\circ} \mathrm{C}$, the reaction mixture was quenched with $1 \mathrm{M} \mathrm{KHSO}_{4}$ and extracted with AcOEt. The organic phase was washed with brine, dried over anhydrous sodium sulfate, filtered, and concentrated under reduced pressure. The residue was purified by flash column chromatography (hexane/AcOEt $=1: 1$ ) to afford 2A (4.00 g, 55\% yield) as a white solid. Mp $169-171{ }^{\circ} \mathrm{C} ;{ }^{1} \mathrm{H}$ NMR $\left(400 \mathrm{MHz}, \mathrm{CDCl}_{3}\right): \delta 4.14(\mathrm{~s}, 3 \mathrm{H}), 2.94(\mathrm{~s}, 4 \mathrm{H}) ;{ }^{13} \mathrm{C}$ NMR (100 $\left.\mathrm{MHz} \mathrm{CDCl}_{3}\right): \delta 173.63,173.27,172.71,163.20,56.96,28.92$; IR (KBr): 2956, 1736, 1560, 1415, 1369, 1288, 1163, 991, 918, $812 \mathrm{~cm}^{-1}$; HRMS (DART) $\mathrm{m} / z:[\mathrm{M}+\mathrm{H}]^{+}$calcd for $\mathrm{C}_{8} \mathrm{H}_{8} \mathrm{ClN}_{4} \mathrm{O}_{3}$ 243.0285; found: 243.0301; anal. calcd for $\mathrm{C}_{8} \mathrm{H}_{7} \mathrm{ClN}_{4} \mathrm{O}_{3}$ : C, 39.60; H, 2.91; N, 23.09. Found: C, 39.43; H, 2.95; N, 22.89.

2-Chloro-4-methoxy-6-phthalimido-1,3,5-triazine (2B). To a toluene solution (100 mL) of 2,4-dichloro-6-methoxy-1,3,5triazine $(2.70 \mathrm{~g}, 15.0 \mathrm{mmol})$, potassium phthalimide $(2.78 \mathrm{~g}$, $15.0 \mathrm{mmol})$ and 18-crown-6 $(0.39 \mathrm{~g}, 1.5 \mathrm{mmol})$ were added at ambient temperature. After stirring for $12 \mathrm{~h}$, the reaction mixture was filtered and washed with AcOEt. After concentrating the filtrate under reduced pressure, the residue was purified by flash column chromatography (hexane/AcOEt $=$ $2: 1)$ to afford 2B (1.68 g, 58\% yield) as a white solid. Mp 163$165{ }^{\circ} \mathrm{C} ;{ }^{1} \mathrm{H}$ NMR $\left(400 \mathrm{MHz}, \mathrm{CDCl}_{3}\right): \delta 8.02(\mathrm{dd}, J=5.5,3.0 \mathrm{~Hz}$, $2 \mathrm{H}), 7.87(\mathrm{dd}, J=5.5,3.0 \mathrm{~Hz}, 2 \mathrm{H}), 4.17(\mathrm{~s}, 3 \mathrm{H}) ;{ }^{13} \mathrm{C}$ NMR $(100$ $\left.\mathrm{MHz}, \mathrm{CDCl}_{3}\right): \delta 173.19,172.40,163.94,162.76,135.46,131.29$, 124.67, 56.74; IR (KBr): 3095, 3064, 2958, 1797, 1739, 1558, 1419, 1353, 1271, 1082, $935 \mathrm{~cm}^{-1}$; HRMS (DART) $\mathrm{m} / \mathrm{z}:[\mathrm{M}+\mathrm{H}]^{+}$calcd for $\mathrm{C}_{12} \mathrm{H}_{8} \mathrm{ClN}_{4} \mathrm{O}_{3}$ 291.0285; found: 291.0282; anal. calcd for $\mathrm{C}_{12} \mathrm{H}_{7} \mathrm{ClN}_{4} \mathrm{O}_{3}$ : C, 49.59; H, 2.43; N, 19.28. Found: C, 49.41; H, $2.50 ; \mathrm{N}, 19.23$.

2-Chloro-4-glutarimido-6-methoxy-1,3,5-triazine (2D). To a THF solution $(1 \mathrm{~mL})$ of sodium hydride $(88 \mathrm{mg}, 2.2 \mathrm{mmol})$, glutarimide $(272 \mathrm{mg}, 2.4 \mathrm{mmol})$ in THF $(5.5 \mathrm{~mL})$ was added at ambient temperature. To this mixture, a THF solution $(0.3 \mathrm{~mL})$ of 18-crown-6 (53 mg, $0.20 \mathrm{mmol})$ and a THF solution $(2.4 \mathrm{~mL})$ of cyanuric chloride (369 mg, $2.0 \mathrm{mmol}$ ) were sequentially added dropwise at $-78{ }^{\circ} \mathrm{C}$. After stirring for $7 \mathrm{~h}$ at ambient temperature, methanol $(10 \mathrm{~mL})$ and $\mathrm{NaHCO}_{3}(336 \mathrm{mg}$, $4.0 \mathrm{mmol}$ ) were added at $0{ }^{\circ} \mathrm{C}$. After stirring for $13 \mathrm{~h}$ at ambient temperature, the reaction mixture was quenched with $1 \mathrm{M}$ $\mathrm{KHSO}_{4}(2 \mathrm{~mL})$ at $0{ }^{\circ} \mathrm{C}$ and extracted with $\mathrm{CH}_{2} \mathrm{Cl}_{2}$. The organic phase was washed with $1 \mathrm{M} \mathrm{KHSO}_{4}$ and brine, dried over anhydrous sodium sulfate, and concentrated under reduced pressure. The residue was purified by flash column chromatography (hexane/AcOEt $=9: 1$ ) to afford 2D (135 mg, 26\% yield) as a white solid. Mp $125-127{ }^{\circ} \mathrm{C} ;{ }^{1} \mathrm{H}$ NMR $(400 \mathrm{MHz}$, $\left.\mathrm{CDCl}_{3}\right): \delta 4.14(\mathrm{~s}, 3 \mathrm{H}), 2.79(\mathrm{t}, J=6.4 \mathrm{~Hz}, 4 \mathrm{H}), 2.14$ (quin, $J=$ $6.4 \mathrm{~Hz}, 2 \mathrm{H}) ;{ }^{13} \mathrm{C}$ NMR $\left(100 \mathrm{MHz}, \mathrm{CDCl}_{3}\right): \delta 173.85,173.13$, 171.19, 167.12, 57.00, 32.35, 17.11; IR (KBr): 3016, 2970, 1743, 1697, 1560, 1539, 1498, 1408, 1358, 1282, 1248, 1144, 1016, 920, 760, 561, $442 \mathrm{~cm}^{-1}$; HRMS (DART) $\mathrm{m} / \mathrm{z}:[\mathrm{M}+\mathrm{H}]^{+}$calcd for $\mathrm{C}_{9} \mathrm{H}_{10} \mathrm{ClN}_{4} \mathrm{O}_{3}$ 257.0441; found: 257.0444; anal. calcd for $\mathrm{C}_{9} \mathrm{H}_{9} \mathrm{ClN}_{4} \mathrm{O}_{3}$ : C, 42.12; H, 3.53; N, 21.83. Found: C, 42.05; H, $3.47 ; \mathrm{N}, 21.83$.

General procedure for the amide-forming reactions (Tables 2, 3, and Fig. 2). To a THF solution ( $2 \mathrm{~mL}$ ) of carboxylic acid 5 $(0.4 \mathrm{mmol})$ and NMM $(53 \mu \mathrm{L}, 0.48 \mathrm{mmol})$, chlorotriazine 2 or CDMT $(0.44 \mathrm{mmol})$ was added. After stirring for $5 \mathrm{~min}$ at ambient temperature, amine $6(0.44 \mathrm{mmol})$ was added to the 
reaction mixture. The reaction was monitored for completion using TLC and quenched with $1 \mathrm{M} \mathrm{KHSO}_{4}(4 \mathrm{~mL})$. The mixture was extracted with $\mathrm{CHCl}_{3}(10 \mathrm{~mL} \times 3)$, and the combined organic layers were washed with $1 \mathrm{~N} \mathrm{HCl}$, sat. $\mathrm{NaHCO}_{3}$, and brine. The organic layer was dried over $\mathrm{Na}_{2} \mathrm{SO}_{4}$, filtered, and concentrated under reduced pressure, and the residue was analyzed by quantitative NMR using coumarin or 1,3,5-trimethoxybenzene as an internal standard. After concentration under reduced pressure, the residue was purified by flash column chromatography with the appropriate eluent to afford amide 7.

$\mathrm{N}$-(4-Ethoxycarbonylphenyl)-3-phenylpropionamide

(7c). The title compound (107 mg, 90\% yield) was obtained by flash column chromatography (hexane/AcOEt $=8: 2$ ) as a white solid. Mp 136-137 ${ }^{\circ} \mathrm{C} ;{ }^{1} \mathrm{H}$ NMR (400 MHz, $\mathrm{CDCl}_{3}$ ): $\delta 7.97$ (d, $J=$ $8.8 \mathrm{~Hz}, 2 \mathrm{H}), 7.52(\mathrm{~d}, J=8.8 \mathrm{~Hz}, 2 \mathrm{H}), 7.52(\mathrm{br}, 1 \mathrm{H}), 7.30-7.20(\mathrm{~m}$, $5 \mathrm{H}), 4.34(\mathrm{q}, J=7.2 \mathrm{~Hz}, 2 \mathrm{H}), 3.04(\mathrm{t}, J=7.6 \mathrm{~Hz}, 2 \mathrm{H}), 2.69(\mathrm{t}, J=$ $7.6 \mathrm{~Hz}, 2 \mathrm{H}), 1.37(\mathrm{t}, J=7.2 \mathrm{~Hz}, 3 \mathrm{H}) ;{ }^{13} \mathrm{C} \mathrm{NMR}\left(100 \mathrm{MHz}, \mathrm{CDCl}_{3}\right)$ : $\delta 170.85,166.32,142.03,140.49,130.85,128.81,128.47,126.60$, 125.97, 118.93, 61.03, 39.60, 31.50, 14.45; IR (KBr): 3317, 3060, 3030, 2983, 2904, 1709, 1670, 1608, 1593, 1523, 1454, 1410, 1363, 1315, $1277 \mathrm{~cm}^{-1}$; HRMS (DART) $\mathrm{m} / z$ : $[\mathrm{M}+\mathrm{H}]^{+}$calcd for $\mathrm{C}_{18} \mathrm{H}_{20} \mathrm{NO}_{3}$ 298.1443; found: 298.1464; anal. calcd for $\mathrm{C}_{18} \mathrm{H}_{19} \mathrm{NO}_{3}$ : C, 72.71; H, 6.44; N, 4.71. Found: C, 72.41; H, $6.34 ; \mathrm{N}, 4.70$.

3,5-Dinitro- $\boldsymbol{N}$-(2-phenethyl)benzamide (7h). The title compound (119 mg, 94\% yield) was obtained by flash column chromatography (hexane/AcOEt $=9: 1$ to $\mathrm{CHCl}_{3}, \mathrm{CHCl}_{3} / \mathrm{AcOEt}$ $=7: 3)$ as a white solid. Mp $155-156{ }^{\circ} \mathrm{C} ;{ }^{1} \mathrm{H}$ NMR $(400 \mathrm{MHz}$, $\left.\mathrm{CDCl}_{3}\right): \delta 9.14(\mathrm{t}, J=2.0 \mathrm{~Hz}, 1 \mathrm{H}), 8.86(\mathrm{~d}, J=2.0 \mathrm{~Hz}, 2 \mathrm{H}), 7.36(\mathrm{t}, J$ $=7.6 \mathrm{~Hz}, 2 \mathrm{H}), 7.29-7.24(\mathrm{~m}, 3 \mathrm{H}), 6.43(\mathrm{br}, 1 \mathrm{H}), 3.80(\mathrm{td}, J=6.9$, $6.9 \mathrm{~Hz}, 2 \mathrm{H}), 3.00(\mathrm{t}, J=6.9 \mathrm{~Hz}, 2 \mathrm{H}) ;{ }^{13} \mathrm{C} \mathrm{NMR}\left(100 \mathrm{MHz}, \mathrm{CDCl}_{3}\right)$ : $\delta 162.91,148.76,138.24,138.16,129.09,128.89,127.22,127.16$, 121.19, 41.83, 35.50; IR (KBr): 3415, 3097, 2945, 1672, 1630, $1603,1541,1527,1487,1452,1435,1346,1327,1306$, $1282 \mathrm{~cm}^{-1}$; HRMS (DART) $m / z:[\mathrm{M}+\mathrm{H}]^{+}$calcd for $\mathrm{C}_{15} \mathrm{H}_{14} \mathrm{~N}_{3} \mathrm{O}_{5}$ 316.0934; found: 316.0936; anal. calcd for $\mathrm{C}_{15} \mathrm{H}_{13} \mathrm{~N}_{3} \mathrm{O}_{5}$ : C, 57.14; H, 4.16; N, 13.33. Found: C, 56.92; H, 4.15; N, 13.31.

$\mathrm{N}$-(4-Ethoxycarbonylphenyl)-6-hydroxyhexanamide (7j). The title compound ( $80 \mathrm{mg}, 75 \%$ yield) was obtained by flash column chromatography $\left(\mathrm{CHCl}_{3} / \mathrm{MeOH}=99: 1\right.$ to $\left.95: 5\right)$ as a white solid. ${ }^{1} \mathrm{H}$ NMR (400 MHz, $\left.\mathrm{CDCl}_{3} / \mathrm{CD}_{3} \mathrm{OD}=1: 1\right): \delta 7.98$ $(\mathrm{d}, J=8.7 \mathrm{~Hz}, 2 \mathrm{H}), 7.68(\mathrm{~d}, J=8.7 \mathrm{~Hz}, 2 \mathrm{H}), 4.36(\mathrm{q}, J=7.2 \mathrm{~Hz}$, $2 \mathrm{H}$ ), $3.59(\mathrm{t}, J=6.6 \mathrm{~Hz}, 2 \mathrm{H}), 2.42(\mathrm{t}, J=7.6 \mathrm{~Hz}, 2 \mathrm{H}$ ), 1.75 (quin, $J$ $=7.6 \mathrm{~Hz}, 2 \mathrm{H}$ ), 1.60 (quin, $J=7.1 \mathrm{~Hz}, 2 \mathrm{H}$ ), 1.45 (quin, $J=7.1 \mathrm{~Hz}$, $2 \mathrm{H}), 1.40(\mathrm{t}, J=7.2 \mathrm{~Hz}, 3 \mathrm{H}) ;{ }^{13} \mathrm{C} \mathrm{NMR}\left(100 \mathrm{MHz}, \mathrm{CDCl}_{3} / \mathrm{CD}_{3} \mathrm{OD}\right.$ $=1: 1): \delta 173.20,166.53,142.76,130.16,124.79,118.62,61.40$, 60.63, 36.70, 31.70, 25.02, 24.99, 13.64; IR (KBr) 3315, 2935, 2868, 1712, 1657, 1610, 1535, 1462, 1439, 1408, 1367, 1282, 1259, 1176, 1103, 1074, 1024, 962, 858, 769, 725, 694, $501 \mathrm{~cm}^{-1}$; HRMS (ESI) $m / z:[\mathrm{M}+\mathrm{Na}]^{+}$calcd for $\mathrm{C}_{15} \mathrm{H}_{21} \mathrm{NNaO}_{4}$ 302.1368; found: 302.1350 .

$\boldsymbol{N}$-Benzyl- $\boldsymbol{N}$-(2-hydroxyethyl)-3-phenylpropanamide (7k). The title compound (95 mg, 84\% yield) was obtained by flash column chromatography (hexane/AcOEt $=1: 1$ ) as a colorless liquid. ${ }^{1} \mathrm{H}$ NMR (400 MHz, $\mathrm{CDCl}_{3}$ ): $\delta$ 7.33-7.05 (m, 10H, major and minor), 4.65 (s, 0.6H, minor), 4.49 (s, $1.4 \mathrm{H}$, major), 3.71 (t, $J=5.0 \mathrm{~Hz}, 1.4 \mathrm{H}$, major), $3.63(\mathrm{t}, J=5.6 \mathrm{~Hz}, 0.6 \mathrm{H}$, minor), 3.53 ( $\mathrm{t}, J=5.0 \mathrm{~Hz}, 1.4 \mathrm{H}$, major), $3.32(\mathrm{t}, J=5.6 \mathrm{~Hz}, 0.6 \mathrm{H}$, minor), 3.01 (t, $J=7.8 \mathrm{~Hz}, 0.6 \mathrm{H}$, minor), $2.98(\mathrm{t}, J=7.8 \mathrm{~Hz}, 1.4 \mathrm{H}$, major), 2.79 (t, $J=7.8 \mathrm{~Hz}, 0.6 \mathrm{H}$, minor), $2.66\left(\mathrm{t}, J=7.8 \mathrm{~Hz}, 1.4 \mathrm{H}\right.$, major); ${ }^{13} \mathrm{C}$ NMR $\left(100 \mathrm{MHz}, \mathrm{CDCl}_{3}\right): \delta 174.88,173.29,141.31,140.95$, 137.63, 136.29, 129.03, 128.65, 128.57, 128.51, 127.94, 127.77, 127.37, 126.31, 126.26, 126.17, 61.87, 59.93, 52.54, 49.95, 48.97, 48.70, 35.17, 35.06, 31.68, 31.56; IR (KBr) 3400, 3086, 3060, 3028, 2931, 2875, 1623, 1496, 1473, 1452, 1421, 1363, 1209, 1076, 1030, 733, $700 \mathrm{~cm}^{-1}$; HRMS (DART) $\mathrm{m} / \mathrm{z}:[\mathrm{M}+\mathrm{Na}]^{+}$calcd for $\mathrm{C}_{18} \mathrm{H}_{21} \mathrm{NNaO}_{2}$ 306.1470; found: 306.1463.

$\boldsymbol{N}$-(2-Hydroxyethyl)- $\boldsymbol{N}$-phenyl-3-phenylpropanamide (7l). The title compound (92 mg, 85\% yield) was obtained by flash column chromatography (hexane/AcOEt $=4: 1$ to $2: 3$ ) as a colorless liquid. ${ }^{1} \mathrm{H}$ NMR $\left(400 \mathrm{MHz}, \mathrm{CDCl}_{3}\right): \delta 7.38-7.30(\mathrm{~m}$, $3 \mathrm{H}), 7.26-7.15(\mathrm{~m}, 3 \mathrm{H}), 7.05$ (d, $J=7.3 \mathrm{~Hz}, 2 \mathrm{H}), 7.02$ (d, $J=$ $7.3 \mathrm{~Hz}, 2 \mathrm{H}), 3.86(\mathrm{t}, J=5.3 \mathrm{~Hz}, 2 \mathrm{H}), 3.74(\mathrm{~d}, J=4.6 \mathrm{~Hz}, 2 \mathrm{H}), 3.38$ (br s, $1 \mathrm{H}), 2.90(\mathrm{t}, J=7.8 \mathrm{~Hz}, 2 \mathrm{H}), 2.36(\mathrm{t}, J=7.8 \mathrm{~Hz}, 2 \mathrm{H}) ;{ }^{13} \mathrm{C}$ NMR (100 MHz, $\left.\mathrm{CDCl}_{3}\right): \delta$ 174.37, 142.66, 140.99, 129.92, 128.52, 128.46, 128.26, 128.06, 126.21, 61.45, 52.92, 36.29, 31.78; IR (KBr) 3400, 3060, 3028, 2931, 2873, 1635, 1595, 1495, 1454, 1408, 1273, 1192, 1074, 1059, 1028, 858, 769, 752, 700, $552,513 \mathrm{~cm}^{-1}$; HRMS (ESI) $\mathrm{m} / z:[\mathrm{M}+\mathrm{Na}]^{+}$calcd for $\mathrm{C}_{17} \mathrm{H}_{19} \mathrm{NNaO}_{2}$ 292.1314; found: 292.1288.

\section{Conflicts of interest}

The authors declare no competing financial interest.

\section{Acknowledgements}

This work was supported by JSPS KAKENHI Grant (No. 26293003, 17H03970, 16K08161).

\section{Notes and references}

1 P. D. Baily, I. D. Collier and K. M. Morgan, in Comprehensive Organic Functional Group Transformations, ed. A. R. Katritzky, O. Meth-Cohn and C. W. Rees, Pergamon, Oxford, 1995, vol. 5, p. 264.

2 M. Parmentier, M. K. Wagner, K. Magra and F. Gallou, Org. Process Res. Dev., 2016, 20, 1104-1107.

3 D.-H. Kim, H.-S. Rho, J. W. You and J. C. Lee, Tetrahedron Lett., 2002, 43, 277-279.

4 A. R. Katritzky, S. K. Singh, C. Cai and S. Bobrov, J. Org. Chem., 2006, 71, 3364-3374.

5 H. Maag, J. Am. Oil Chem. Soc., 1984, 61, 259-267.

6 T. Maugard, M. Remaud-Simeon, D. Petre and P. Monsan, Tetrahedron, 1997, 53, 5185-5194.

7 Y. Park, X. Fei, Y. Yuan, S. Lee, J. Hur, S. J. Park, J.-K. Jung and S.-Y. Seo, RSC Adv., 2017, 7, 41955-41961.

8 M. Kunishima, C. Kawachi, K. Hioki, K. Terao and S. Tani, Tetrahedron, 2001, 57, 1551-1558.

9 M. Kunishima, T. Ujigawa, Y. Nagaoka, C. Kawachi, K. Hioki and M. Shiro, Chem.-Eur. J., 2012, 18, 15856-15867. 
10 M. Kunishima, K. Yoshimura, H. Morigaki, R. Kawamata, K. Terao and S. Tani, J. Am. Chem. Soc., 2001, 123, 1076010761.

11 M. Kunishima, H. Imada, K. Kikuchi, K. Hioki, J. Nishida and S. Tani, Angew. Chem., Int. Ed., 2005, 44, 7254-7257.

12 M. Kunishima, D. Kato, N. Kimura, M. Kitamura, K. Yamada and K. Hioki, Beilstein J. Org. Chem., 2016, 12, 1897-1903.

13 C. Hansch, A. Leo and R. W. Taft, Chem. Rev., 1991, 91, 165195.

14 F. Milletti, L. Storchi, L. Goracci, S. Bendels, B. Wagner, M. Kansy and G. Cruciani, Eur. J. Med. Chem., 2010, 45, 4270-4279.

15 C. S. Petersen, Acta Chem. Scand., 1971, 25, 379-389.

16 R. Mason, Acta Crystallogr., 1961, 14, 720-724.

17 Without NMM, the reaction in $\mathrm{MeOH}$ did not proceed smoothly.

18 There is a possibility that $\mathbf{8}$ could be formed from $\mathbf{2 , 1 0}$, or 11.

19 P. J. Black, M. G. Edwards and J. M. J. Williams, Eur. J. Org. Chem., 2006, 2006, 4367-4378.

20 C. Salomé and H. Kohn, Tetrahedron, 2009, 65, 456-460.
21 T. Takuwa, T. Minowa, H. Fujisawa and T. Mukaiyama, Chem. Pharm. Bull., 2005, 53, 476-480.

22 M. Kunishima, K. Yamamoto, Y. Watanabe, K. Hioki and S. Tani, Chem. Commun., 2005, 2698-2700.

23 I. Shiina and Y. Kawakita, Tetrahedron, 2004, 60, 4729-4733. 24 K. Hioki, S. Kameyama, S. Tani and M. Kunishima, Chem. Pharm. Bull., 2007, 55, 825-828.

25 V. P. Srivastava, A. K. Yadav and L. D. S. Yadav, Synlett, 2014, 25, 665-670.

26 C. M. Boehner, D. M. Marsden, H. F. Sore, D. S. Norton and D. R. Spring, Tetrahedron Lett., 2010, 51, 5930-5932.

27 L. S. Baugh and J. A. Sissano, J. Polym. Sci., Part A: Polym. Chem., 2002, 40, 1633-1651.

28 K. Sasaki and D. Crich, Org. Lett., 2011, 13, 2256-2259.

29 R. A. Rodriguez, P.-S. Pan, C.-M. Pan, S. Ravula, S. Lapera, E. K. Singh, T. J. Styers, J. D. Brown, J. Cajica, E. Parry, K. Otrubova and S. R. McAlpine, J. Org. Chem., 2007, 72, 1980-2002.

30 T. Xu, F. Sha and H. Alper, J. Am. Chem. Soc., 2016, 138, 66296635.

31 L. Wang, B. P. Lieberman, K. Ploessl and H. F. Kung, Nucl. Med. Biol., 2014, 41, 58-67. 